\title{
Soil Water Release Curves : Indicator to Suit Sustainable Cropping Scheme under Sloppy Rain-Fed Climatic Conditions of Pothowar Plateau of Punjab-Pakistan
}

\section{Rehmat Ullah ${ }^{*}$, Shehzada Munawar Mehdi ${ }^{2}$, Khalid Saif Ullah Khan ${ }^{1}$, Aftab Ahmed Sheikh$^{2}$, Sigit Mujiharjo ${ }^{3}$, and Muhammad Saud ${ }^{4}$}

\author{
${ }^{1}$ Dept. of Soil Science \& Soil and Water Conservation, Pir Mehr Ali Shah, Arid Agriculture \\ University, Rawalpindi, Pakistan \\ 2 Directorate of Soil Fertility Survey \& Testing Institute, Thokar Niaz Baig, Lahore, Pakistan \\ ${ }^{3}$ Dept. of Agricultural Technology, Faculty of Agriculture, University of Bengkulu, Indonesia \\ ${ }^{4}$ Department of Sociology, Airlangga University, Surabaya, Indonesia
}

\section{*Email address: rehmat1169@yahoo.com}

\begin{abstract}
In arid environment, limitations of crop productivity could be improved by soil management practices like soil conservation measures, tillage and reducing slopes through terracing on different cropping patterns. These patterns include area as Wheat-Maize (WMCP) and Wheat-Fodder (WFCP) in Kahuta (high rainfall climatic area), Wheat-Millet-Fallow (WMFCP) and Wheat- Millet-Lentil (WMLCP) in Khairimurat (medium rainfall climatic area) and Wheat-Fallow (WFCP) and Fallow-Groundnut (FGCP) in Pindi Gheb (low rainfall climatic area). In areas that have more crop water requirements the yield of these crops has been affected when the drought prevails. Our results evidenced that more average soil water content (ASWC) was available in high to medium height terraces in WMCP and low to medium in WFCP of Kahuta area. ASWC remained more in high to medium height terraces under all cropping pattern of Khairimurat during September. ASWC remained more in low to medium height terraces under all cropping pattern of Pindi Gheb during September and December. Equidistantly, soil water release curve also indicated that medium rainfall sites had more plant water availability as compared to high and low rainfall sites. Yield relationship to plant water availability revealed significance for intrusion of modified cropping patterns rather than existing cropping patterns on sustained basis. Finally, our study suggests that cropping patterns of high and low rainfall areas should adjusted by growing low water requirement crops in summer seasons to cope the drought period for the sustainability of agriculture under rainfed climatic conditions.
\end{abstract}

Keywords: cropping patterns, Pothowar Plateau, soil water contents, soil water release curve, sloppy lands Citation to this paper should be made as follows :

Ullah, R., S. M. Mehdi, K. S. U. Khan, A. A. Sheikh, S. Mujiharjo, and M. Saud. · 2018. Soil Water Release Curves: Indicator to Suit Sustainable Cropping Scheme under Sloppy Rain-Fed Climatic Conditions of Pothowar Plateau of Punjab-Pakistan. Agritropica: Journal of Agricultural Science. 1 (1): 9-24. DOI: https://doi.org/10.31186/J.Agritropica.1.1.9-24

\section{INTRODUCTION}

Globally, among total area (510 million sq. km), land occupies 148.9 million sq. km $(70.8 \%)$ and 361.1 million sq. $\mathrm{km}$ area $(29.2 \%)$ is under water. Upon land, arable crops and permanent crops occupy an area of 14.98 and 1.498 million sq $\mathrm{km}$ area respectively (Worldgeography website). Moreover, arid and semi-arid regions have been comprised up to
$6.8 \times 10^{7}$ sq. $\mathrm{km}$ (Worldatlas website). However, such areas faces various issues such as erratic rainfall, temporal variation, soil erosion, soil fertility depletion, soil salinity/sodicity and some time severe drought conditions resulting in low crop productivity and severe food shortage. These areas have been reported to be sloppy lands depending upon rainfall for crop production. Such types of lands are often sandy in nature with low water and/or nutrient 
holding capacity (Masto et al., 2007) and poor microbiological activities (Ullah et al., 2013). Therefore, the sloppy lands mostly modified into terrace cultivation for agriculture purpose (Sang-Arun et al., 2006).

In Pakistan, water losses through conveyance $(50 \%)$ from available water (144 MAF) do not meet the crop water requirement (Tarar 1997). Pothowar region (latitude of 32010 to 3409 North and longitude of 71010 to 73055 East) has great potential for crop production. Rainfall distribution (Robertson 1985) in summer $(70 \%)$ \& winter $(30 \%)$ season is erratic and sometimes drought conditions also prevail, therefore, due to depletion of soil water, crops yields are severely affected (Ullah et al., 2009). However, proper management of sloppy lands such as development of terraces (Qiu et al., 2001), growing of cereals (Wang et al., 2008), peral millets (Michels and Bielders 2005.) and leguminous crops (Singh et al., 2008) on these sloppy lands can conserve water and automatically prevent loss of soil fertility (Moradi et al., 2015; Zhang et al., 2015). The currently used cropping patterns are not in harmony with the rainfall pattern. However, water restoration approaches might be practiced by establishing water retention curves on different rainfall patterns. Empirical and practical implications of water release curves might help to understand the scheduling of irrigation strategy to reduce the water scarcity (Strehmel et al., 2016). However, many approaches have been linked as novel approaches to mitigate the water scarcity wisely through soil conservation strategies (Dörner, et al., 2015). However, much advancement had been made out to find out the easy way approach on existing pedological characteristics. For this consequence, Crawford et al. (1995) developed relationship between the moisture-release curve and structure of soil in order to manage the water scarcity in existing soil environmental conditions. However, Groenevelt and Grant (2004) also predicted new model approach for the soil-water retention curve in order to solve issues of residual water contents. Hodnett and Tomasella (2002) have developed new water retention pedo-transfer functions specified for temperate to tropical soils. Moreover, Jones HG (2007) had monitored plant and soil water status through novel water retention approach in drought prone environmental conditions. Therefore, Paramasivam and Fares (2000) have evaluated soil water status using tensiometers in a sandy soil profile under citrus production. Saxton et al. (1985) estimated generalized soil-water characteristics from various textures in their studies. Tomasella J and Hodnett MG (1998) also developed soil water retention characteristics curves in their experiments at Amazonia. Therefore, many scientists have overlooked the importance of water release curve in different soils at their various experimental sites.

Prior to this, existing sites possess cropping patterns more than 50 years. These patterns include Wheat-Maize and WheatMaize as Fodder in Kahuta, Wheat-MilletFallow and Wheat-Millet-Lentil in Khairimurat and Wheat-Fallow and Fallow-Groundnut in Pindi Gheb area. Therefore, the high delta crops such as maize, millet are included in the cropping pattern of Pothowar Plateau. The crop water requirement of these crops is high because the availability of soil water from rainfall does not match with these crops. Keeping in view of these facts, present study has been planned with the hypothesis to evaluate the soil water availability, emphasizing suitability of crops on basis of plant water availability, soil fertility status and to suggest viable options to match suitable crops on sustained basis.

\section{RESEARCH AND METHODS}

\section{Study Sites and Soil Sampling}

The experimental sites are geographically located in Pothowar region possessing three ecological zones on the basi 
of rainfall. High rainfall areas include Kahuta (336' $07^{\prime}$ north latitude and $73^{\circ} 48^{\prime} 13^{\prime}$ east longitude) having 750 to $1000 \mathrm{~mm}$ annual precipitation. Medium rainfall areas include Khairimurat (72080'22' north latitude and 33 $47^{\prime} 41^{\prime}$ ' east longitude) having 250 to $600 \mathrm{~mm}$ annual precipitation. The low rainfall areas include Pindi Gheb (72026'66' north latitude and 33'23'19' east longitude) having less than 250 $\mathrm{mm}$ annual precipitation. All of these areas were visited and selected for experimental purpose from high, medium and low rainfall areas. These sites are located at a distance of 40 , 85 and $165 \mathrm{~km}$ away from Islamabad, respectively. On these sites, mean maximum of the hottest month (June) ranges to $42^{\circ} \mathrm{C}$ while, the mean minimum of coldest month (January) ranges from $4.5^{0}$ to $6.5^{\circ} \mathrm{C}$. Broad base terraces are the most common (95\%). Generally, the existing sloppy soils having high height terrace (6meters above from medium height terrace), medium height terrace ( 5 meters above from low height terrace) and low terraces (7 meter above from the normal existing fields) had been made by the farming community. Wheat-Maize (WMCP), Wheat-Fodder (WFCP), Wheatmillet-Fallow (WMFCP), Wheat-Millet-Lentil
(WMLCP), Wheat-Fallow (WFCP) and fallowGroundnuts (FGCP) cropping system are constantly adopted by the farming community more than 50 years. All experimental sites had variable soil quality characteristics (Table 1). The soil samples were collected from these cropping patterns (Figure 1) for analyses of soil water contents, soil water release curves and bulk density. The soil water contents have been monitored monthly throughout year. For this purpose, soil samples were collected monthly from 9 points from distance of 12 feet away from each other at $0-90 \mathrm{~cm}$ soil depth with an interval of $15 \mathrm{~cm}$ soil depth of each terrace and each cropping patterns. The soil water content was determined through gravimetric method. Soil samples $(0-30 \mathrm{~cm}$ depths) were collected for soil fertility analyses from the selected sites. These were air dried, grounded with wooden mortar \& pestle, passed through $2 \mathrm{~mm}$ sieve and kept for further fertility analyses. Soil bulk density samples were collected through core method from these sites. Climatic data such as rainfall (Figure 2) was obtained from the Pakistan meteorological department, Islamabad.

\section{Table 1 Soil physical properties of experimental sites}

\begin{tabular}{|c|c|c|c|c|c|c|c|c|}
\hline $\begin{array}{c}\text { Experimental } \\
\text { Sites }\end{array}$ & $\begin{array}{l}\text { Cropping } \\
\text { Patterns }\end{array}$ & Soil Terraces & $\begin{array}{l}\text { Depth } \\
\text { (cm) }\end{array}$ & Texture & $\begin{array}{c}\text { Bulk } \\
\text { density } \\
\left(\mathrm{Mg} \mathrm{m}^{-3}\right)\end{array}$ & $\begin{array}{l}\text { Particle } \\
\text { Density } \\
\left(\mathrm{Mg} \mathrm{m}^{-3}\right)\end{array}$ & $\begin{array}{c}\text { Porosity } \\
(\%)\end{array}$ & $\begin{array}{c}\text { Plant } \\
\text { Available } \\
\text { Water (\%) }\end{array}$ \\
\hline \multirow{6}{*}{ Kahuta } & \multirow{3}{*}{ WM } & High & $0-30$ & \multirow{3}{*}{$\begin{array}{l}\text { Sandy } \\
\text { Loam }\end{array}$} & $1.46 \pm 0.04$ & 2.65 & $44.90 \pm 0.04$ & $6.92 \pm 0.04$ \\
\hline & & Medium & $0-30$ & & $1.46 \pm 0.03$ & 2.65 & $44.90 \pm 0.04$ & $6.89 \pm 0.04$ \\
\hline & & Low & $0-30$ & & $1.46 \pm 0.04$ & 2.65 & $44.90 \pm 0.04$ & $7.01 \pm 0.04$ \\
\hline & \multirow{3}{*}{ WF } & High & $0-30$ & Sandy & $1.36 \pm 0.05$ & 2.65 & $48.68 \pm 0.04$ & $9.73 \pm 0.04$ \\
\hline & & Medium & $0-30$ & Clay & $1.37 \pm 0.04$ & 2.65 & $48.30 \pm 0.04$ & $9.69 \pm 0.04$ \\
\hline & & Low & $0-30$ & Loam & $1.35 \pm 0.02$ & 2.65 & $49.05 \pm 0.04$ & $9.71 \pm 0.04$ \\
\hline \multirow{6}{*}{ Khairimurat } & \multirow{3}{*}{ WMF } & High & $0-30$ & $\begin{array}{l}\text { Sandy } \\
\text { Loam }\end{array}$ & $1.46 \pm 0.04$ & 2.65 & $44.90 \pm 0.04$ & $11.68 \pm 0.04$ \\
\hline & & Medium & $0-30$ & \multirow{2}{*}{ Loam } & $1.42 \pm 0.04$ & 2.65 & $46.41 \pm 0.04$ & $11.66 \pm 0.04$ \\
\hline & & Low & $0-30$ & & $1.38 \pm 0.04$ & 2.65 & $47.92 \pm 0.04$ & $11.72 \pm 0.04$ \\
\hline & \multirow{4}{*}{ WML } & High & $0-30$ & & $1.36 \pm 0.04$ & 2.65 & $48.67 \pm 0.04$ & $12.18 \pm 0.04$ \\
\hline & & Medium & $0-30$ & Loam & $1.39 \pm 0.04$ & 2.65 & $47.54 \pm 0.04$ & $12.09 \pm 0.04$ \\
\hline & & Low & $0-30$ & & $1.37 \pm 0.04$ & 2.65 & $48.30 \pm 0.04$ & $12.21 \pm 0.04$ \\
\hline \multirow{6}{*}{ Pindi Gheb } & & High & $0-30$ & Sandy & $1.36 \pm 0.04$ & 2.65 & $48.67 \pm 0.04$ & $8.03 \pm 0.04$ \\
\hline & \multirow[t]{3}{*}{ WF } & Medium & $0-30$ & Clay & $1.37 \pm 0.04$ & 2.65 & $48.30 \pm 0.04$ & $8.09 \pm 0.04$ \\
\hline & & Low & $0-30$ & Loam & $1.35 \pm 0.04$ & 2.65 & $49.05 \pm 0.04$ & $8.10 \pm 0.04$ \\
\hline & & High & $0-30$ & Sandy & $1.37 \pm 0.04$ & 2.65 & $48.30 \pm 0.04$ & $7.62 \pm 0.04$ \\
\hline & \multirow[t]{2}{*}{ FG } & Medium & $0-30$ & Clay & $1.36 \pm 0.04$ & 2.65 & $48.67 \pm 0.04$ & $7.59 \pm 0.04$ \\
\hline & & Low & $0-30$ & Loam & $1.35 \pm 0.04$ & 2.65 & $49.05 \pm 0.04$ & $7.61 \pm 0.04$ \\
\hline
\end{tabular}

Note: \pm is standard Deviation in which the average values varied among each other at Probability level of $5 \%$. 


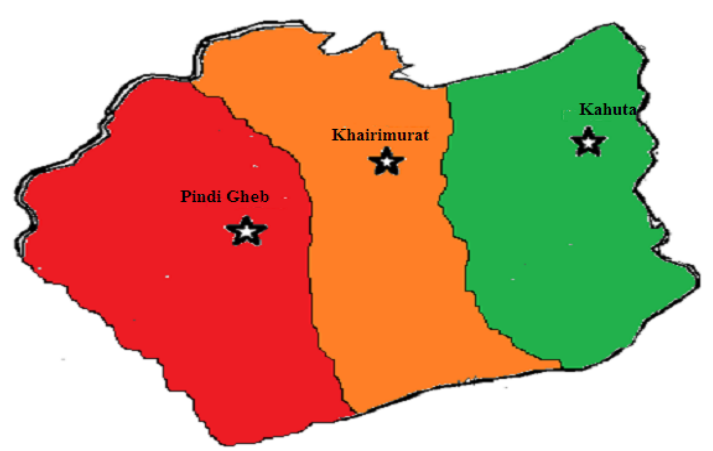

Figure 1 Annotating The Sampling And Experimental Sites Of High (33066'07' North Latitude and 73048'13' East Longitude), Medium (72080'22' North Latitude and 33047'41' East Longitude) and Low (72026'66' North Latitude And 33023'19' East Longitude) Rainfall Areas.

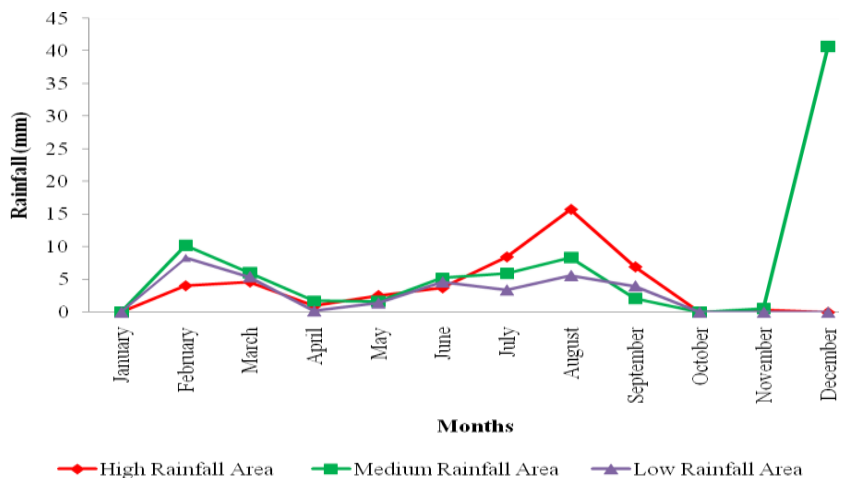

Figure 2 Rainfall Distribution at Experimental Site throughout the Year in High, Medium And Low Rainfall Areas.

\section{Soil Analyses}

Soil particle size distribution was determined by using Bouyoucos Hydrometer method (Black 1965). Soil textural grade was determined by using Triangle from USDA (Gee and Bauder 1986). Soil bulk density was determined by the core method (Grossman and Reinsch 2002) using $5.4 \mathrm{~cm}$ diameter and $6.0 \mathrm{~cm}$ long cores. Soil porosity was determined by particle size distribution method established by Kilmer and Alexander (1949). Soil water content was determined by gravimetric method (Hess 1971). Plant available water was determined through method established by Cassel and Nielsen (1986). In this regard, difference method on the bases of field capacity and wilting point data derived through water release curves was adopted. Soil water release curves were developed using pressure membrane apparatus. Undisturbed soil samples from soil soil core were allowed to stand at least 16 hours with an access of water on the plate in laboratory. These were placed in pressure cooker and pressure of $0.10,0.25,0.50$, $0.75,1.0,1.5,2.0,2.5,3.5,5.0,10.0$ and 15.0 bars was applied. After 48 hours, samples were removed from initiating the extraction or when readings on a burette indicate that outflow has ceased from all of the samples on each plate. Then such samples were subjected for estimation of soil water content by gravimetric method (Richards 1954).

$\mathrm{pH}$ of 1:1 soil water suspension was measured using $\mathrm{pH}$ meter having combination electrode model 05669-20 by Cole Parmer Ltd. (Mc Lean 1982.). The electrical conductivity of 1:1 soil water suspension was measured by using Electrical Conductivity Meter at $25^{\circ} \mathrm{C}$ model Inolab E 163694, Germany. Calcium plus Magnesium in the soil saturation extract was determined by titration with standard EDTA and following the Method established in USDA Hand Book 60 (Richards 1954). Exchangeable soil potassium and sodium in the extract were determined by Emission Spectroscopy using flame photometer (Knudsen et al., 1982). 
Available soil phosphorous was also determined on spectroscopic method established by Olsen and Sommers (1982). Total organic carbon was estimated by using absorption spectroscopy method (FAO, 1974). Total soil nitrogen was determined by using Kjeldahl distillation apparatus method established by Buresh et al. (1982). Cation exchange capacity was determined through emission spectroscopy using flame photometer at $767 \mathrm{~nm}$ wavelength (Rhoades 1982). Calcareousness $\left(\mathrm{CaCO}_{3}\right)$ was determined through titrimetric method (FAO 1974).

\section{Data analyses}

The investigations depicted are in arithmetic means and average of each sample replicated thrice from all experimental sites for soil water contents, soil physical \& chemical characteristics were calculated and the standard deviation was tested at a 5\% probability using one way ANOVA. All the statistical analyses were performed by using Stat View 5.0 (SAS Inst., Inc.) (Steel et al., 1997). Regression model was also employed with this program to identify the dependent variable (yield) on all other variable.

\section{RESULTS AND DISCUSSION}
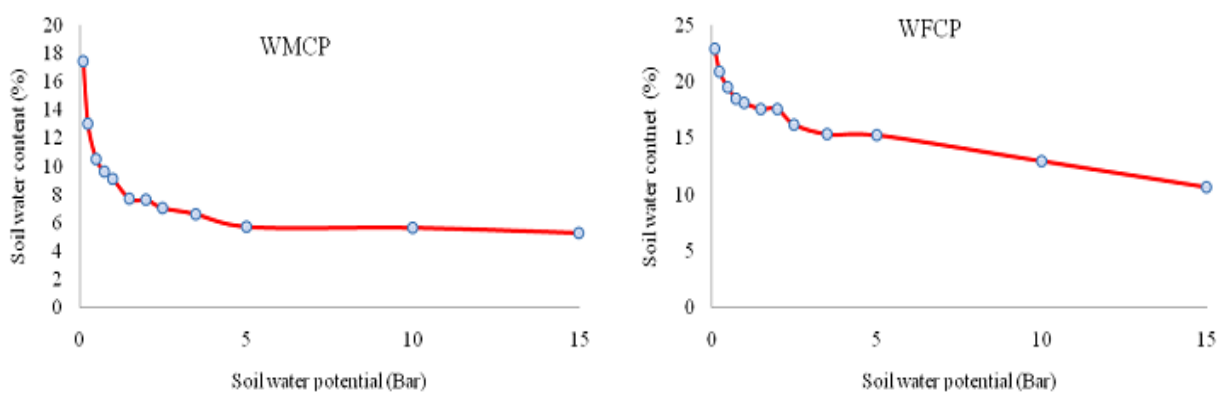

Figure 3 Soil water release curves of Wheat-Maize Cropping Pattern and Wheat-Fodder Cropping Pattern of Kahuta areas

Soil water contents of high rainfall areas (Kahuta sites)

soil water contents (ASWC) of samples collected up to 0-90 $\mathrm{cm}$ soil depth with an interval of $15 \mathrm{~cm}$ varied significantly. Data
Water release curve of high rainfall areas (Kahuta sites)

The data revealed that WMCP and WFCP possessed sandy loam and sandy clay textural class, respectively. Predominantly, WMCP retained $18 \%$ while WFCP possessed $28 \%$ clay content. Soil water release curve under both cropping pattern (Figure 3) depicted that the soil of both $\mathrm{CP}$ retained more soil water at field capacity and less at permanent wilting point. WFCP had higher plant water availability $(9.75 \%)$ while minimum plant water availability $(6.9 \%)$ was present in WMCP. The data revealed that maximum water retention in WFCP was attributed to owing high clay content than to WMCP. That is why, variation in plant water availability in all soil terraces might be due to textural variation in both cropping patterns. Bulk density (BD) was noted $1.46 \mathrm{Mg} \mathrm{m}^{-3}$ in all height terraces of WMCP while remained 1.36, 1.37, $1.35 \mathrm{Mg} \mathrm{m}^{-3}$ in high, medium and low height terraces of WFCP at kahuta areas. Particle density was $2.65 \mathrm{Mg} \mathrm{m}^{-3}$ in all terraces of this site. This site has less soil porosity in their existing cropping patterns than Pindi Gheb and Khairmurat areas. 
was non-significantly higher in September $(18.11 \%)$ as compared to March and July to Feb. ASWC remained non-significantly different among high, medium and low height terraces throughout the year. However, ASWC responded in this order that high height terraces $>$ medium height terraces $>$ low height terraces. ASWC under WFCP resulted significantly higher in July and September than all other months but remained almost similar on all types of terraces. As a whole, ASWC retained more in high and medium terraces in WMCP while low and medium terraces in WFCP as compared to other terraces, respectively throughout the year.
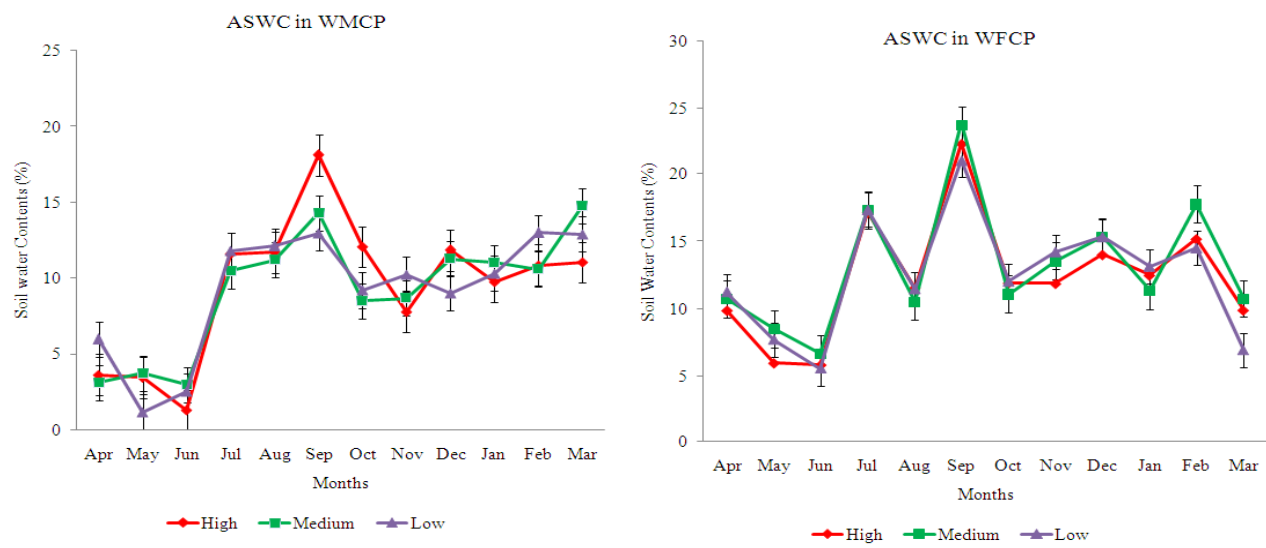

Figure 4 Average soil water contents (ASWC) in all height terraces of Wheat-Maize and Wheat-Fodder Cropping patterns (WMCP-WFCP) at Kahuta areas

Soil water release curve of medium determined by gravimetric method also varied rainfall areas (Khairimurat sites)

Data of soil samples (15 cm depth) collected from Wheat-Millet-Fallow (WMFCP) and Wheat-Millet-Lentil cropping pattern (WMLCP) in Khairimurat (Figure 5) varied significantly for soil water release curve. However, samples passed through pressure membrane apparatus at pressure of $0.10,0.25$, $0.50,0.75,1.0,1.5,2.0,2.5,3.5,5.0,10.0$ and 15.0 responded invariably. The soil water content significantly under both cropping patterns. The textural class of both cropping pattern was also Loam predominantly containing $25 \%$ clay content. Trend of soil water release curve under both cropping pattern retained more soil water at field capacity and less at permanent wilting point. Both cropping patterns had more plant water availability (12.18 and $11.68 \%)$ as compared to soils of Kahuta and Pindi Gheb areas.
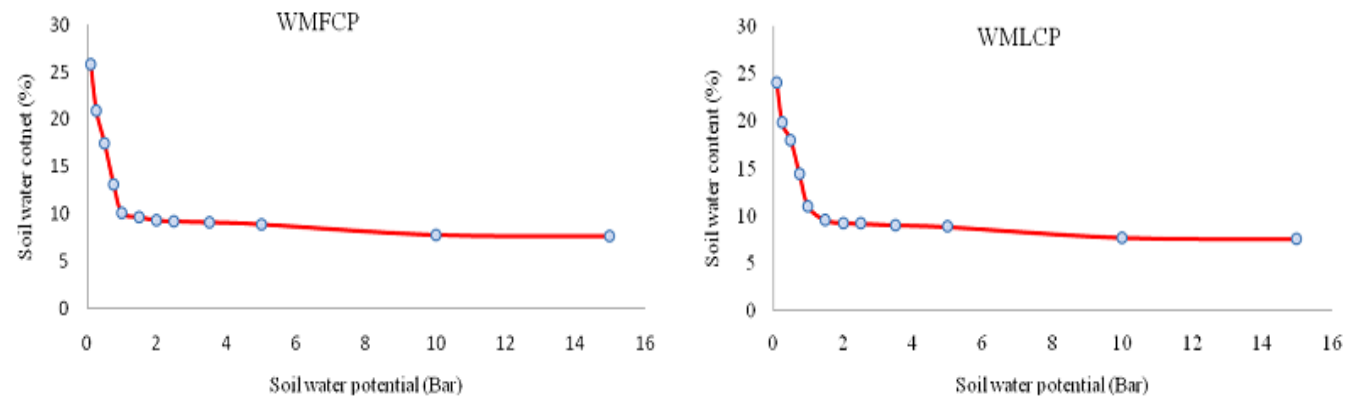

Figure 5 Soil water release curves of Wheat-Millet-Fallow Cropping Pattern and WheatMillet-Lentil Cropping Pattern of Khairimurat areas.

However, higher plant water terraces. BD was 1.46, 1.42, 1.38, in high, availability in both cropping patterns might be medium and low height terraces of WMFCP due to presence of loam in soil of all height and also was 1.36, 1.39, 1.37, in high, medium 14 | Ullah et al : Soil Water Release Curves: Indicator to Suit Sustainable Cropping Scheme... 
and low height terraces of WMLCP at Kahirimurat areas. Particle density was $2.65 \mathrm{Mg}$ $\mathrm{m}^{-3}$ in all soil terraces of this area. Khairmurat sites have more porosity in their existing cropping patterns than Kahuta areas.

\section{Soil water contents at medium rainfall areas (Khairimurat sites)}

The data (Figure 6) regarding soil water contents (ASWC) under Wheat-Millet-Fallow (WMFCP) and Wheat-Millet-Lentil cropping patterns (WMLCP) varied significantly in all height terraces. Under WMFCP, ASWC was significantly lower in October to November \& in March and non-significantly higher in April to August, December and Feb than other months at all height terraces. However, it was significantly higher in September and January as compared to other months. It retained in all height terraces in this way; high terraces > medium terraces $>$ low terraces respectively throughout the whole year. More ASWC in that period was due to heavy rains. ASWC under WMFCP was significantly lower from May to July, October to November and March as compared to all other months and was nonsignificantly higher in April, August, December and February in all the terraces. However, it was measured significantly higher during September and January than other months in all terraces. Our results annotated that high height terraces had retained more ASWC throughout the year than to medium and low terraces under both cropping patterns.
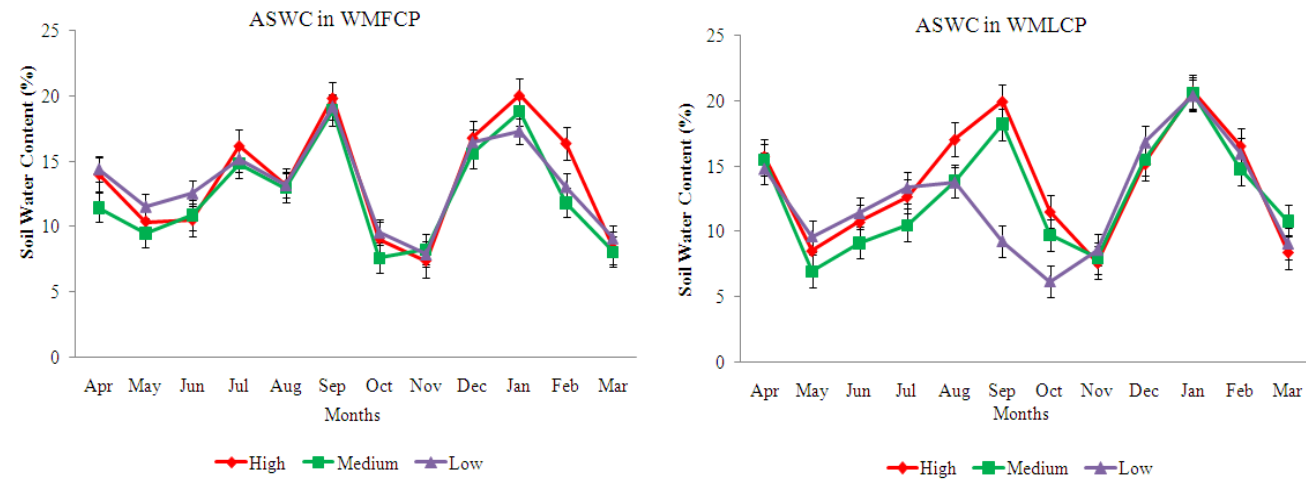

Figure 6 Average soil water contents (ASWC) in all height terraces of Wheat-Millet-Fallow and Wheat-Millet-Lentil cropping patterns (WMFCP-WMLCP) at Khairmurat areas.

Soil water release curve of low rainfall areas (Pindi Gheb sites)

Our data revealed that textural class of Wheat-Fallow (WFCP) and Fallow Groundnut cropping pattern (FGCP) was Sandy Clay Loam having $24 \%$ clay content. Soil water release curve (Figure 7) under both cropping pattern responded significantly. Our data depicted that the soil of both cropping patterns retained more soil water at field capacity and less at permanent wilting point. Both cropping patterns of these areas restored more plant water availability (8.03 and $7.62 \%$ ) than Kahuta area soil that may be attributed to dominancy of Sandy Clay loam in the soil of all height terraces. BD was 1.36, 1.37, 1.35, in high, medium and low height terraces of WFCP and also was 1.37, 1.36, 1.35, in high, medium and low height terraces of FGCP at Pindi Gheb areas. Particle density was $2.65 \mathrm{Mg} \mathrm{m}^{-3}$ in all slopes of this area. Pindi Gheb sites have more porosity in their existing cropping patterns than Khairimurat and Kahuta areas. 

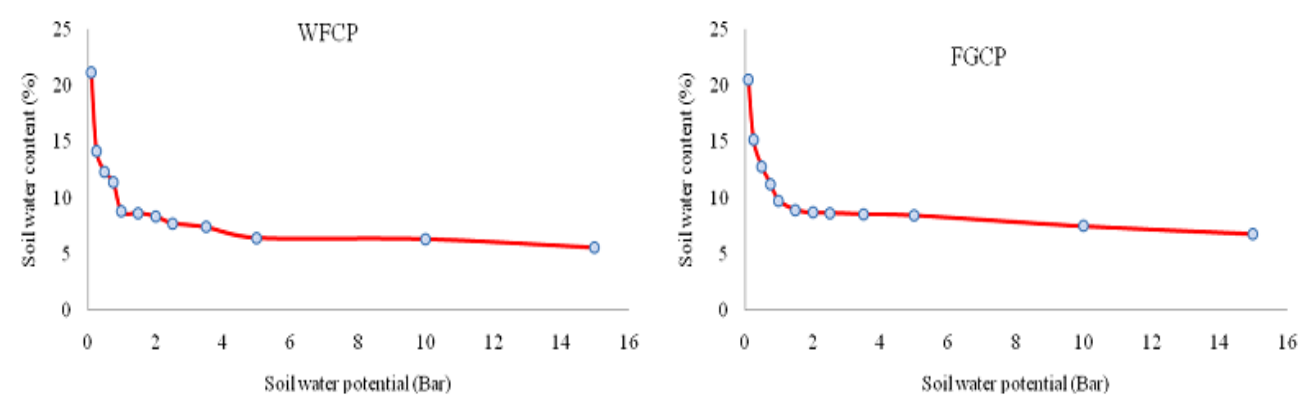

Figure 7 Soil water release curves of Wheat-Fallow Cropping Pattern and Fallow-Groundnut Cropping Pattern of Pindi Gheb areas.

Soil water contents of low rainfall areas (Pindi Gheb sites)

The data (Figure 8) of average soil water contents (ASWC) under Wheat-Fallow (WFCP) and Fallow-Groundnut cropping patterns (FGCP) varied significantly in all height terraces. ASWC in WFCP was non-significantly less from April to June, October to November

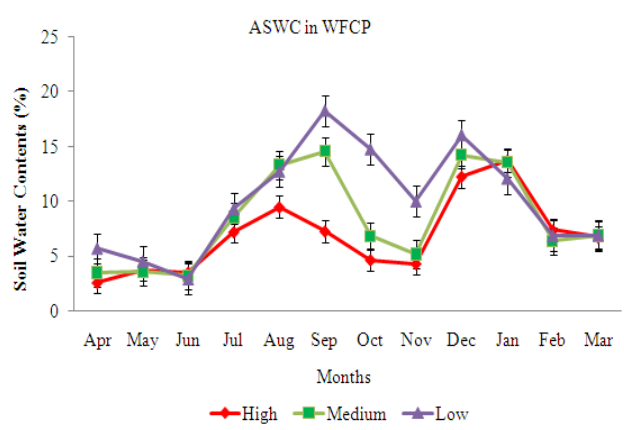

Figure 8 Average soil water contents (ASWC) in all height terraces of Wheat-Fallow and Fallow-Groundnut cropping patterns (WFCP-FGCP) at Pindi Gheb areas.

ASWC in FGCP was available more in low terraces as compared to medium and high height terraces, respectively in April. It increased significantly in May and decreased significantly in June with almost uniform distribution in high, medium and low terraces. After this, it increased significantly till November in this way; low height terraces > high height terraces and medium height terraces, respectively. Afterwards, it increased highly significant during December due to heavy rains in this trend; high terraces > medium terraces $>$ low terraces, respectively

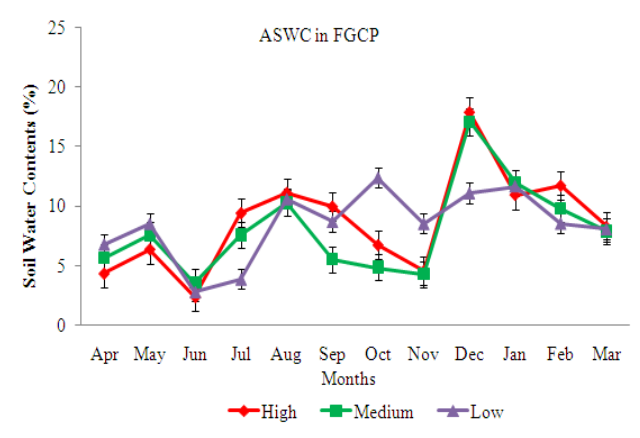

and Feb to March than other months in this way; low terraces $>$ medium terraces $>$ high terraces, respectively. It was non-significantly more from July to August, December to January in this trend as low terraces $>$ medium terraces $>$ high terraces, respectively. However, it was significantly more in September at low and medium terraces than high terraces.

and then decreased significantly till March. Collectively, ASWC was more in low height terraces as compared to medium and high height terraces respectively throughout the year.

Soil chemical characteristics of high, medium and low rainfall areas

The data pertaining to soil fertility status under WMCP and WFCP (Table 2) revealed that it varied significantly $(P \leq 0.05)$ in soil profile from top to bottom in all height terraces. 
Table 2. Soil chemical characteristics of experimental sites

\begin{tabular}{|c|c|c|c|c|c|c|c|}
\hline \multirow[b]{2}{*}{ Rainfall Areas } & \multirow{2}{*}{$\begin{array}{c}\text { Cropping } \\
\text { Patterns }\end{array}$} & \multirow{2}{*}{$\begin{array}{c}\text { Soil } \\
\text { Terraces }\end{array}$} & \multicolumn{5}{|c|}{ Soil Chemical Characteristics } \\
\hline & & & $\mathrm{pHs}$ & $\begin{array}{c}\text { ECe } \\
\left(\mathrm{ds} \mathrm{m}^{-1}\right)\end{array}$ & $\begin{array}{c}\text { CEC } \\
\left(\text { meq100g-1) }^{-1}\right)\end{array}$ & $\mathrm{CaCO}_{3}(\%)$ & $\begin{array}{c}\text { TOC } \\
(\%)\end{array}$ \\
\hline \multirow{7}{*}{ Kahuta } & \multirow{3}{*}{ WM } & High & $7.43 \pm 0.03$ & $0.32 \pm 0.02$ & $13.65 \pm 0.21$ & $7.90 \pm 0.28$ & $0.54 \pm 0.06$ \\
\hline & & Medium & $7.46 \pm 0.03$ & $0.29 \pm 0.03$ & $14.37 \pm 0.30$ & $7.50 \pm 0.57$ & $0.63 \pm 0.03$ \\
\hline & & Low & $7.54 \pm 0.04$ & $0.33 \pm 0.04$ & $14.64 \pm 0.66$ & $6.30 \pm 0.57$ & $0.52 \pm 0.01$ \\
\hline & \multirow{4}{*}{ WF } & High & $6.87 \pm 0.08$ & $0.29 \pm 0.06$ & $12.09 \pm 2.80$ & $5.15 \pm 0.78$ & $0.46 \pm 0.04$ \\
\hline & & Medium & $6.94 \pm 0.09$ & $0.32 \pm 0.02$ & $13.40 \pm 1.81$ & $6.25 \pm 1.63$ & $0.42 \pm 0.06$ \\
\hline & & Low & $7.00 \pm 0.00$ & $0.26 \pm 0.07$ & $14.77 \pm 0.62$ & $6.45 \pm 1.06$ & $0.40 \pm 0.13$ \\
\hline & & High & $7.98 \pm 0.04$ & $0.37 \pm 0.03$ & $12.15 \pm 0.08$ & $7.94 \pm 0.75$ & $0.32 \pm 0.04$ \\
\hline \multirow{5}{*}{ Khairimurat } & \multirow[t]{3}{*}{ WMF } & Medium & $7.83 \pm 0.13$ & $0.41 \pm 0.03$ & $12.21 \pm 0.16$ & $7.97 \pm 0.76$ & $0.33 \pm 0.04$ \\
\hline & & Low & $8.05 \pm 0.06$ & $0.38 \pm 0.02$ & $12.25 \pm 0.19$ & $7.49 \pm 1.50$ & $0.35 \pm 0.06$ \\
\hline & & High & $7.83 \pm 0.06$ & $0.36 \pm 0.01$ & $12.23 \pm 0.22$ & $8.41 \pm 1.45$ & $0.31 \pm 0.04$ \\
\hline & \multirow[t]{3}{*}{ WML } & Medium & $7.93 \pm 0.08$ & $0.31 \pm 0.06$ & $12.36 \pm 0.07$ & $6.47 \pm 1.51$ & $0.33 \pm 0.05$ \\
\hline & & Low & $7.96 \pm 0.04$ & $0.35 \pm 0.07$ & $12.38 \pm 0.10$ & $8.02 \pm 2.20$ & $0.45 \pm 0.11$ \\
\hline \multirow{7}{*}{ Pindi Gheb } & & High & $8.95 \pm 0.02$ & $0.38 \pm 0.07$ & $8.56 \pm 0.64$ & $7.07 \pm 0.99$ & $0.30 \pm 0.06$ \\
\hline & \multirow[t]{3}{*}{ WF } & Medium & $7.72 \pm 0.17$ & $0.37 \pm 0.02$ & $10.13 \pm 0.13$ & $8.93 \pm 0.33$ & $0.36 \pm 0.04$ \\
\hline & & Low & $8.25 \pm 0.02$ & $0.36 \pm 0.06$ & $11.25 \pm 0.05$ & $7.42 \pm 1.15$ & $0.32 \pm 0.01$ \\
\hline & & High & $7.80 \pm 0.03$ & $0.35 \pm 0.01$ & $5.31 \pm 0.40$ & $6.95 \pm 0.30$ & $0.14 \pm 0.01$ \\
\hline & \multirow[t]{2}{*}{ FG } & Medium & $7.80 \pm 0.22$ & $0.36 \pm 0.01$ & $5.59 \pm 0.67$ & $9.60 \pm 0.52$ & $0.26 \pm 0.02$ \\
\hline & & Low & $7.83 \pm 0.08$ & $0.37 \pm 0.03$ & $5.45 \pm 0.20$ & $8.11 \pm 0.24$ & $0.32 \pm 0.03$ \\
\hline & $\begin{array}{l}\text { Cropping } \\
\text { Patterns }\end{array}$ & $\begin{array}{c}\text { Soil } \\
\text { Terrace }\end{array}$ & $\begin{array}{c}\text { Total } \\
\text { Nitrogen } \\
(\%) \\
\end{array}$ & $\begin{array}{c}\text { Available } \\
\text { Phosphorus } \\
\left(\mu \mathrm{g} \mathrm{g}^{-1}\right)\end{array}$ & $\begin{array}{c}\text { Soluble } \\
\text { Potassium } \\
\left(\text { meq L-1) }^{-1}\right.\end{array}$ & $\begin{array}{l}\text { Soluble } \\
\text { Sodium } \\
(\text { meq L-1) }\end{array}$ & $\begin{array}{l}\mathrm{Ca}+\mathrm{Mg} \\
\left(\mathrm{meq} \mathrm{L}^{-1}\right)\end{array}$ \\
\hline \multirow{7}{*}{ Kahuta } & \multirow{4}{*}{ WM } & High & $0.075 \pm 0.006$ & $4.40 \pm 0.99$ & $2.85 \pm 0.23$ & $3.01 \pm 0.11$ & $0.33 \pm 0.03$ \\
\hline & & Medium & $0.069 \pm 0.007$ & $4.25 \pm 0.49$ & $3.22 \pm 0.17$ & $3.11 \pm 0.16$ & $0.40 \pm 0.01$ \\
\hline & & Low & $0.055 \pm 0.002$ & $5.10 \pm 0.28$ & $2.89 \pm 0.22$ & $3.30 \pm 0.01$ & $0.44 \pm 0.04$ \\
\hline & & High & $0.039 \pm 0.003$ & $5.95 \pm 0.21$ & $3.17 \pm 0.03$ & $1.97 \pm 0.15$ & $0.35 \pm 0.01$ \\
\hline & \multirow[t]{3}{*}{ WF } & Medium & $0.043 \pm 0.008$ & $6.20 \pm 0.71$ & $3.51 \pm 0.24$ & $2.47 \pm 0.56$ & $0.39 \pm 0.04$ \\
\hline & & Low & $0.039 \pm 0.002$ & $6.40 \pm 0.42$ & $3.57 \pm 0.74$ & $2.93 \pm 0.78$ & $0.42 \pm 0.12$ \\
\hline & & High & $0.025 \pm 0.002$ & $3.65 \pm 0.23$ & $2.46 \pm 0.04$ & $3.13 \pm 0.31$ & $0.39 \pm 0.03$ \\
\hline \multirow{5}{*}{ Khairimurat } & \multirow[t]{3}{*}{ WMF } & Medium & $0.026 \pm 0.003$ & $3.68 \pm 0.25$ & $2.62 \pm 0.09$ & $4.04 \pm 0.27$ & $0.51 \pm 0.11$ \\
\hline & & Low & $0.028 \pm 0.004$ & $3.69 \pm 0.25$ & $2.64 \pm 0.07$ & $2.98 \pm 0.35$ & $0.43 \pm 0.08$ \\
\hline & & High & $0.026 \pm 0.003$ & $3.65 \pm 0.25$ & $2.23 \pm 0.07$ & $2.71 \pm 0.66$ & $0.44 \pm 0.11$ \\
\hline & \multirow[t]{3}{*}{ WML } & Medium & $0.030 \pm 0.007$ & $3.61 \pm 0.21$ & $2.29 \pm 0.06$ & $2.35 \pm 0.27$ & $0.47 \pm 0.07$ \\
\hline & & Low & $0.031 \pm 0.004$ & $3.72 \pm 0.25$ & $2.33 \pm 0.10$ & $2.82 \pm 0.24$ & $0.46 \pm 0.02$ \\
\hline \multirow{6}{*}{ Pindi Gheb } & & High & $0.036 \pm 0.001$ & $3.38 \pm 0.45$ & $4.61 \pm 0.32$ & $2.01 \pm 0.22$ & $0.51 \pm 0.15$ \\
\hline & \multirow[t]{3}{*}{ WF } & Medium & $0.044 \pm 0.002$ & $4.65 \pm 0.64$ & $4.15 \pm 0.32$ & $2.17 \pm 0.01$ & $0.55 \pm 0.03$ \\
\hline & & Low & $0.033 \pm 0.002$ & $4.05 \pm 0.21$ & $4.47 \pm 0.16$ & $4.44 \pm 0.06$ & $0.57 \pm 0.05$ \\
\hline & & High & $0.026 \pm 0.007$ & $2.46 \pm 0.19$ & $4.41 \pm 0.14$ & $2.88 \pm 0.04$ & $0.53 \pm 0.06$ \\
\hline & \multirow[t]{2}{*}{ FG } & Medium & $0.037 \pm 0.005$ & $3.13 \pm 0.22$ & $3.85 \pm 0.13$ & $2.32 \pm 0.09$ & $0.54 \pm 0.04$ \\
\hline & & Low & $0.0497 \pm 0.01$ & $3.82 \pm 0.28$ & $4.02 \pm 0.06$ & $1.78 \pm 0.09$ & $0.50 \pm 0.02$ \\
\hline
\end{tabular}

Note: \pm is standard Deviation in which the average values varied among each other at Probability level of $5 \%$.

It depicted that the soil was alkaline in nature, non-saline and non-sodic due to ECe and low sodium concentration under both cropping patterns. The soil was calcareousness in nature having sufficient TOC and total nitrogen, adequate soil potassium but deficient in available phosphorus. The CEC responded maximum potential of soil to adsorb available nutrients for crop productivity. However, WMCP retained almost higher liberation of nutrients as compared to WFCP in all terraces. However, WMCP retained more nutrition in medium terraces than too high and low height terraces from the normal elevated field while WFCP liberated much nutrition on low height terraces accordingly. WMFCP, WMLCP of khairimurat and WFCP, FGCP of pindi gheb varied significantly $(P \leq 0.05)$ for total organic carbon and other fertility attributes in all height terraces but retained almost similar chemical characteristic like to Kahuta area.

\section{Rainfall distribution of all sites}

Rainfall distribution throughout the year (early shown in Figure 2) annotated that it 
rained more $(15.69 \mathrm{~mm})$ during August as compared to other months throughout the year due to onset of monsoon season; while remained less minimum $(0.0 \mathrm{~mm})$ during October in high rainfall areas. However, maximum (15.69 $\mathrm{mm}$ ) rainfall was observed during February \& August as compared to other months throughout the year and very less $(0.0 \mathrm{~mm})$ during January in medium rainfall areas. Prior to this, heavy showers were also noted during February \& August and very light rainfall distribution was observed during January, October, November and December.

\section{Relationship of yield to plant water availability}

Figure 9 presents the relationship of yield of existed and modified cropping patterns along with plant water availability.
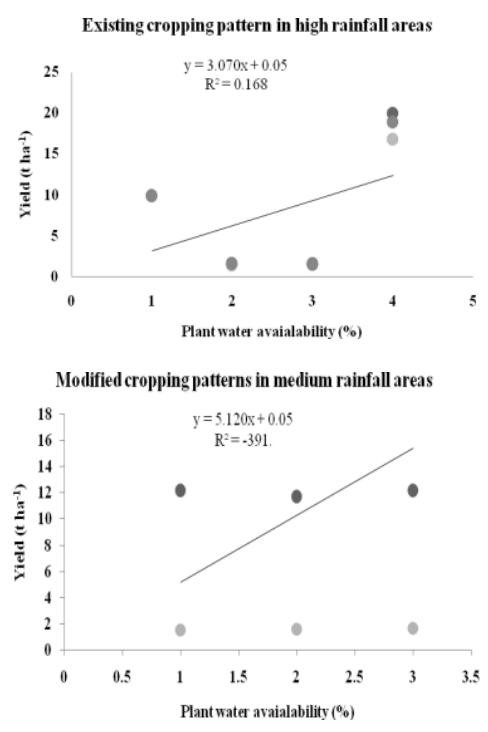
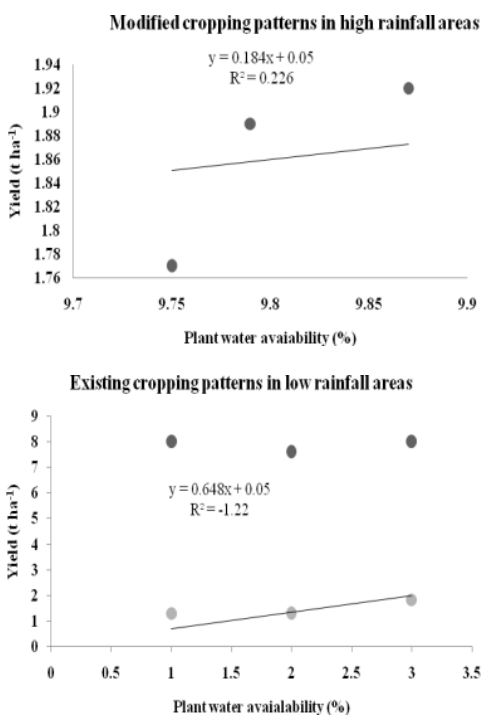
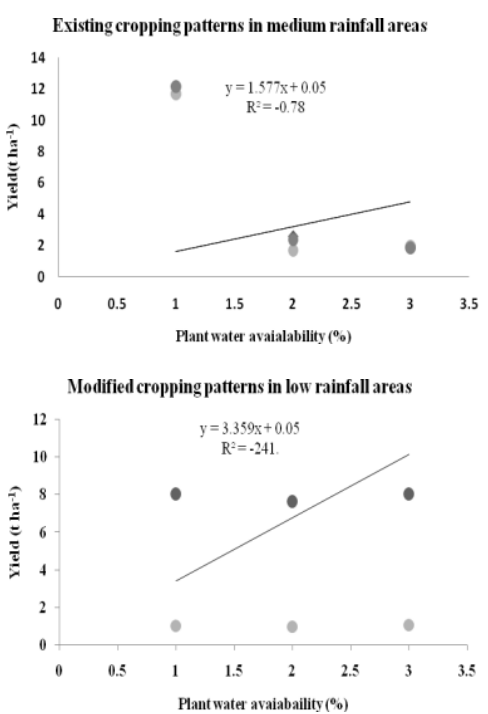

Figure 9 Regression relationship oh high rainfall areas possessing existing Wheat-Maize Cropping Pattern, Wheat Fodder Cropping Pattern \& modified Wheat-Mungbean Cropping Pattern, medium rainfall areas having existing Wheat- Millet Fallow Cropping Pattern, Wheat-Millet-Lentil Cropping Pattern \& modified WheatMungbean Cropping Pattern and low rainfall areas comprising existing WheatFallow Cropping Pattern, Fallow-Groundnut Cropping Pattern \& modified WheatMungbean Cropping Pattern.

In this consequence, relationship of yield of existed and modified cropping patterns along with plant water availability (Figure 9) revealed significant $(P \leq 0.05)$ suitability of low delta crop in all soil terraces. However, existing (WMCP, WFCP) cropping patterns produced less $\left(\mathrm{r}^{2}=0.168\right)$ yields as compared to modified cropping pattern like wheat-mungbean $(\mathrm{WMCP})\left(\mathrm{r}^{2}=0.226\right)$ on the basis of plant water availability. Prior to this, existing (WMFCP, WMLCP) of medium rainfall area gave less $\left(\mathrm{r}^{2}\right.$ $=-0.78$ ) yields as compared to modified (wheatmungbean-lentil) cropping pattern $\left(\mathrm{r}^{2}=0.391\right)$ depending on plant water availability. At low rainfall areas, existing cropping patterns like Wheat-Fallow and Fallow-Groundnut (WFCP,
FGCP) significantly returned less $\left(\mathrm{r}^{2}=-1.22\right)$ yield as compared to modified cropping patterns like wheat-mungbean $(\mathrm{WMCP})\left(\mathrm{r}^{2}=\right.$ 2.41) based on available plant water contents.

\section{DISCUSSION}

In arid environment, soil productivity might be sustained through adopting restorative crops rather than exhaustive crops by using balanced fertilizers, organic matter and optimum soil water availability. Same consequences are also present in Pothowar region. However, our study revealed that sloppy lands in terrace cultivation are the viable option for the sustainability of cropping patterns. Unfortunately, such terraces had also to Suit Sustainable Cropping Scheme... 
shown heterogenic trend in soil fertility and soil water contents. Our data showed that soil water content retained more in high and medium terraces under WMCP, while low and medium under WFCP as compared to other terraces in Kahuta (high rainfall) area (Figure 4). This might be due to cultivation of high delta crops such as maize, low organic matter content, vegetation, textural variation and maximum drainage due to poor embankment. In this regard, Wang et al. (2008) grown millet, spring wheat, potatoes and peas in different rotation and found that soil water retention (97.7\%) \& yield were greatly influenced by rainfall. They recommended that soil water contents in slope gradient might be restored by growing cover crops. Our results are in same symmetry to their results that growing of cover crops restore more soil water contents. In addition to this, Kizito et al. (2007) reported that shrubs being cover crop used less soil water contents and restored more moisture in soil than to other food crops on uneven lands.

Their recommendations also verify our data that growing of cover crops improve soil water availability on sloppy lands. Prior to this, ASWC retained more in high terraces as compared to other terraces under WMFCP and WMLCP (Figure 6) at Khairimurat (medium rainfall) area. In general, low terraces had retained less average soil water content on both sites of khairimurat. It could be attributed to growing of high delta crops such as millet, poor embankment and unevenness of this terrace, low organic matter content and low drainage of upper terraces. ASWC (Figure 8) retained more in low and medium terraces under WFCP and FGCP at Pindi Gheb (low rainfall) area. Low soil water contents on high terrace under both cropping patterns might be due to the high elevation site, direct exposure to the sunlight, low organic matter content, low infiltration, poor embankment of the site and also keeping the land fallow for a longer period. Studies of $\mathrm{Fu}$ et al. (2003) revealed that the soil water content increases significantly along the slope gradients which direly depend on rainfall distribution. However, Malik et al. (2006) suggested positive response of maize with application of fertilizer but negative with low water and fertility status. Besides this, Michels and Bielders (2005) recommended that restorative crops on sloppy lands conserve soil water content efficiently and also maintain soil fertility. However, thematic theories of these scientists do match to our investigations about soil water availability in various rainfall distributed areas.

Soil water release curves (Figure 3, 5 and 7) indicated their heterogenic trend in all cropping patterns of all height terraces due to various textural classes. Saxton et al. (1985), Crawford (1995), Javier and Hodnett (1998), Hodnett and Tomasella (2002), Groenevelt and Grant (2004), Paramasivam et al. (2000), Jones (2007) and Epila et al., 2017 established water release curves which behaved differently due to variety of soil textures to various crops in various experimental sites. Their results behave similar to our findings. However, growth of the crop is entirely dependent on plant water availability. It is evident from our data (Table 1) that medium rainfall site soils had more plant water availability as compared to high and low rainfall site soils. This variation in plant water availability might be due to the textural variation on site specific. Role of many scientists such as de Boodt and Verdonck 1971; Chang et al., 1977; Morgan et al., 2001; Dalvi et al., 2010; Debnath et al., 2012 and Huang et al. (2017) depicted that plant growth remained suitable at optimum plant water availability while wilt under stress at wilting point. Hence, all the discussed data do exactly match to our investigation pertaining to plant water availability on terraced soils existing in different rainfall areas. It had been suggested from their observation that supplemental irrigation might be managed during drought period if possible. Our soil fertility status (Table 2) reflected the deficiency of soil nutrition and 
which need remedial through fertilizer application in all sites. In this consortium, $\mathrm{Li}$ and Lindstrom (2001) found that nutrient index increased down to slope gradient in existing arid environamtal conditions.

The sustainability of terrace cultivation depends on many factors especially water scarcity. Our data (Figure 9) elucidated the significant relationship amid yield and plant water availability between existing and modified cropping patterns in arid to humid environmental areas. However, availability of water has prime importance for the sustainability of agro-ecosystem of our country. Under drought prevailing situation, the low delta crops are only option to feed the population on sustained basis. The adoption of cover and low water requirement crops in the arid conditions improves the soil fertility and infiltration rate. In this regards, many scientists such as Kaneko et al., 1998; Radulovich et al., 1989; Livingston and Jong 1991; Tejada et al., 2006; Singh et al., 2008; Hermassi \& Lamachère 2013 and Deb et al., 2014 have indicated that cover crops on sloppy lands conserved more soil water content and soil fertility status. From all consequences, it is evident that when drought prevails in the arid areas during summer seasons then the availability of water becomes scarce.

\section{CONCLUSION AND RECOMMENDATIONS}

Our data suggested that special soil conservation techniques might be opted to conserved maximum moisture on upper part of bench terraces and lower part of broad base terraces during April to June. Soil water release curves indices that medium rainfall sites restored more plant water availability than to others and which may become precursor for growing of suitable crops on these sites. Soil fertility results advocated for the application of optimum nutrition to sustain the yield index of crops. However, it was also suggested that high delta crop like maize might be replaced with low delta crop in all terraces of high rainfall areas. However, only summer crop such as millet should be changed by inducting mungbean variety in medium rainfall areas. In low rainfall areas, fallow land might be cultivated with mungbean rather than keeping it fallow. This practice would provide net return to the farmers by improving their socioeconomic status. The sustainability of the cropping patterns is viable option such as adoption of low water requirement crops such as mung bean in water scarce areas. Hence, adoption of these viable options would lead to improve the yield based on plant water availability for sustainability of our agroecosystem.

\section{REFERENCES}

Black, C. A. 1965. Methods of Soil Analysis. American Society of Agronomy Inc. Publishers, Madison, Wilsconsin, USA.

Buresh, R. J., E. R. Austin, and E. T. Craswell. 1982. Analytical method in N-15 research. Fertilizer Research. 3: 37-62. California Fertilizer Association. Soil Improvement Committee, 1980. Western Fertilizer Handbook. $6^{\text {th }}$ (ed) Interstate Printers and Publishers. Danville, Ill, USA. DOI: 10.1007/BF01063408

Cassel, D. K., and D. R. Nielsen. 1986. Field capacity and available water capacity. Methods of Soil Analysis: Part 1-Physical and Mineralogical Methods, (methods of soil anl), pp. 901-926.

Chang, A. C., L. J. Lund, A. L. Page, and J. E. Warneke. 1977. Physical properties of fly ash-amended soils. Journal of Environmental Quality 6(3): 267270.DOI: 10.2134/jeq1977.0047242500060003000 $7 x$. 
Crawford, J. W., N. Matsui, and I. M. young. 1995. The relation between the moisture-release curve and the structure of soil. European Journal of Soil Science 46(3): 369-375. DOI: 10.1111/j.1365-2389.1995.tb01333.x

Dalvi, V. B., M. B. Nagdeve, and L. N. Sethi. 2010 Rain water harvesting to develop non-arable lands using Continuous Contour Trench (CCT). Assam University Journal of Science and Technology 4(2): 54-57.

de Boodt, M. A. V. O., and O. Verdonck. 1971. The physical properties of the substrates in horticulture. In III Symposium on Peat in Horticulture 26 (pp. 37-44). DOI: 10.17660/ActaHortic.1972.26.5

Deb P, P. Debnath, and S. K. Pattanaaik. 2014. Physico-chemical properties and water holding capacity of cultivated soils along altitudinal gradient in South Sikkim, India. Indian Journal of Agricultural Research 48(2): 120-126.

Debnath, P., P. Deb, D. Sen, S. K. Pattannaik, D. Sah, and S. K. Ghosh. 2012. Physicochemical properties and its relationship with water holding capacity of cultivated soils along altitudinal gradient in Sikkim. International Journal of Agriculture, Environment and Biotechnology 5(2): 161-166.

Dörner, J., J. Huertas, J. G. Cuevas, C. Leiva, L. Paulino, and J. L. Arumí. 2015. Water content dynamics in a volcanic ash soil slope in southern Chile. Journal of Plant Nutrition and Soil Science 178(4): 693702.

Epila, J., N. J. De Baerdemaeker, L. L. Vergeynst, W. H. Maes, H. Beeckman, and K. Steppe. 2017. Capacitive water release and internal leaf water relocation delay drought-induced cavitation in African Maesopsis eminii. Tree physiology 37(4): 481-490.

FAO, 1974. The Euphrates Pilot Irrigation Project. Methods of soil analysis, Gadel Soil Laboratory (A Laboratory manual). Food and Agriculture Organization, Rome, Italy.

Fu, B., J. Wang, L. Chen, and Y. Qiu. 2003. The effects of land use on soil moisture variation in the Danangou catchment of the Loess Plateau, China. Catena. 54(1-2): 197-213. DOI: 10.1016/S03418162(03)00065-1.

Gee, G. W., and J. W. Bauder. 1986. Particle size analysis. In. Klute. A. (ed). Methods of soil analysis. Part I. American Society of Agronomy. No. 9. Madison, Wisconsin. pp. 383-411.

Groenevelt, P. H., and C. D. Grant. 2004. A new model for the soil-water retention curve that solves the problem of residual water contents. European Journal of Soil Science 55(3): 479-485. DOI: 10.1111/j.1365-2389.2004.00617.x

Grossman, R. B., and T. G. Reinsch. 2002. Bulk density and linear extensibility. In: Warren, A.D. (Ed.), Methods of Soil Analysis. Part 4. American Society of Agronomy, Monograph 9, Madison, WI, USA, pp. 201-240

Hermassi, T., and J. M. Lamachère. 2013. Hydrological impact of traditional water harvesting techniques: Case study of Tunisian Contour benches. In Book of Proceedings pp. 5. 
Hess, P. R. 1971. A text book of Soil Chemicals Analysis. John Murray, London, UK.

Hodnett, M. G., and J. Tomasella. 2002. Marked differences between van Genuchten soil water-retention parameters for temperate and tropical soils: a new water-retention pedo-transfer functions developed for tropical soils. Geoderma 108(3-4): 155-180.

Huang, C. W., J. C. Domec, E. J. Ward, T. Duman, G. Manoli, A. J. Parolari, and G. G. Katul. 2017. The effect of plant water storage on water fluxes within the coupled soil-plant system." New Phytologist 213 (3): 1093-1106.

Jones, H. G. 2007. Monitoring plant and soil water status: established and novel methods revisited and their relevance to studies of drought tolerance. Journal of Experimental Botany 58(2): 119-130. DOI: $10.1093 / \mathrm{jxb} / \mathrm{erl118}$

Kaneko, Y., S. Nakamura, K. Sakai, T. Aoyagi, A. Kikuchi, Y. Sakurai, and T. Okano.1998. Rapid deswelling response of poly (Nisopropylacrylamide) hydrogels by the formation of water release channels using poly (ethylene oxide) graft chains. Macromolecules 31(18): 60996105. DOI: $10.1021 / \mathrm{ma} 971899 \mathrm{~g}$.

Kilmer, V. J., and L. T. Alexander. 1949. Methods of making mechanical analyses of soils. Soil Science 68: 15-24.

Kizito, F., M. Sene, M. I. Dragila, A. Lufafa, I. Diedhiou, E. Dossa, R. Cuenca, J. Selker., and R. P. Dick. 2007. Soil water balance of annual crop-native shrub systems in Senegal's Peanut Basin: The missing link. Agriculture and Water Management 90(1-2): 137-148. DOI: 10.1016/j.agwat.2007.02.015.
Knudsen, D., G. A. Peterson, and P. F. Pratt. 1982. Lithium, sodium, and potassium. Methods of soil analysis. Part 2. Chemical and microbiological properties, (methods of soil ana) pp. 225-246.

Li, Y., and M. J. Lindstrom. 2001. Evaluating soil quality-soil redistribution relationship on terraces and steep hill slope. Soil Science Society of America Journal 65: 1500-1508. DOI: 10.2136/sssaj2001.6551500x

Livingston, N. J., and E. D. Jong. 1991. The use of unsaturated salt solutions to generate conifer needle water-release curves. Canadian Journal of Forest Research 21(1): 53-57. DOI: 10. 1139/x91-008

Malik, M. A., M. Ansar F. Zahoor, and I. Ahmad. 2006. Effect of organic and inorganic fertilizers on fodder yield of Maize and its subsequent effect on soil. Pakistan Journal of Agricultural Engineering and Veterinary Science 22(2): 5-15.

Masto, R. E., P. K. Chhonkar, D. Singh and A. K. Patra. 2007. Soil quality response to long-term nutrient and crop management on a semi-arid Inceptisol. Agriculture, Ecosystems \& Environment 118(1): 130-142. DOI: 10.1016/j.agee.2006.05.008.

Mc Lean, E. O. 1982 Soil $p H$ and lime requirement. pp. 199-224. In Page AL (ed.), Methods of Soil analysis, part 2: Chemicals and Microbiological properties. American Society of Agronomy, Madison, WI, USA.

Michels, K., and C. L. Bielders. 2005. Pearl millet growth on an erosion-affected soil in the Sahel. Experimental 
Agriculture 42:

1-17.DOI: 10.1017/S0014479705002899.

Moradi, A., C. T. B. Sung, K. J. Goh, A. H. M. Hanif, and C. F. Ishak. 2015. Effect of four soil and water conservation practices on soil physical processes in a non-terraced oil palm plantation. Soil and Tillage Research 145: 62-71.

Morgan, K. T, L. R. Parsons, and T. A. Wheaton. 2001. Comparison of laboratory-and field-derived soil water retention curves for a fine sand soil using tensiometric, resistance and capacitance methods. Plant and Soil 234(2): $\quad$ 153-157.

10.1023/A:1017915114685

Olsen, S. R., and L. E. Sommers. 1982. Phosphorus. pp. 403-430. In Page AL (ed.), Methods of soil analysis, Agronomy. No.9, Part 2: Chemical and microbiological properties, 2nd ed., American Society of Agronomy, Madison, WI, USA.

Paramasivam, S., A. K. Alva and A. Fares. 2000. An evaluation of soil water status using tensiometers in a sandy soil under citrus production. Soil Science 165(4): 343-353.

Qiu, Y., B. J. Fu, J. Wang, and L. Chen. 2001. Soil moisture variation in relation to topography and land use in a hill slope catchment of the Loess Plateau, China. Journal of Hydrology 240: 243-263. DOI: $\underline{10.1016 / S 0022-1694(00) 00362-0}$

Radulovich, R., E. Solorzano, and P. Sollins. 1989. Soil macropore size distribution from water breakthrough curves. Soil Science Society of America Journal 53(2): 556-559.
Richards, L. A. 1954. Diagnosis and improvement of saline and alkali soils. USDA Agriculture Handbook 60. Washington, D.C., USA.

Robertson, G. W. 1985. Rainfall probabilities in Rawalpindi-Islamabad area. BARD, PARC, Islamabad, Pakistan. pp:1-29.

Sang-Arun, J., Mihara, M., Horaguchi, Y. and Yamaji, E., 2006. Soil erosion and participatory remediation strategy for bench terraces in northern Thailand. Catena, 65(3), pp.258-264. Doi:10.1016/j.catena.2005.11.010.

Saxton, K. E., W. J. Rawls, J. S. Romberger, and R. I. Papendick. 1985. Estimating generalized soil-water characteristics from texture. Soil Science Society of America Journal 50(4): 1031-1036. DOI: 10.2136/sssaj1986.036159950050000400 $39 x$.

Singh, K. K., Ch. Srinivasarao, and M. Ali. 2008. Phosphorus and mung bean residue incorporation improve soil fertility and crop productivity in sorghum and mung bean-lentil cropping system. Journal of Plant Nutrition 31: 459-471. Steel, R. G. D., J. A. Torrie, and D. A. Dickey. 1997. Principles and Procedures of Statistics, 3rd.McGraw Hill Book Co. Inc., New York, USA, pp. 428-434.

Strehmel, A., A. Jewett, R. Schuldt, B. Schmalz, and N. Fohrer. 2016. Field data-based implementation of land management and terraces on the catchment scale for an eco-hydrological modelling approach in the three gorges region, China. Agricultural Water Management 175: $\quad$ 43-60. 
Tarar, R. N. 1997. Pakistan water surface scenario in $21^{\text {th }}$ Century and needed actions. International Symposium: Water for the 21th Century. June 17-19, 1997, Lahore.

Tejada, M., M. T. Hernandez and C. Garcia. 2006. Application of two organic amendments on soil restoration: effects on the soil biological properties. Journal of Environmental Quality 35: 1010-1017. DOI: 10.2134/jeq2005.0460.

Tomasella, J., and M. G. Hodnett. 1998. Estimating soil water retention characteristics from limited data in Brazilian Amazonia. Soil Science 163(3): 190-222.

Ullah R, M. I. Lone, K. S. Khan, S. M. Mehdi and M. A. Qazi. 2013. Effect of cropping systems and seasonal variations on soil microbial biomass and enzymatic activities in arid soils.
Journal of Animal and Plant Sciences 23(2): 493-499.

Ullah R, M. I. Lone, S. Ali, and S. Hussain. 2009. Soil water variation under different cropping patterns on sloppy lands in Punjab. Soil \& Environment 28(2): 156161.

Wang, X., G. Sun, Y. Jia, F. M. Li, and J. Z. Xu. 2008. Crop yield and soil water restoration on 9-year -old alfalfa pasture in the semi arid loess plateau of China. Agricultural Water Management 95: 171-198. DOI: 10.1016/j.agwat.2007.10.001.

Zhang, Y., Gao, J., Wu, L.N., Li, H., Bai, X., Li, J. and Li, X., 2015. The study of terraced field erosion based on the scale model in the Loess Plateau under extreme rainstorm conditions. Nature Environment and Pollution Technology 14(2): 267 